\begin{tabular}{cc} 
Revista de & Journal of Integrated \\
GESTÃO COSTEIRA Integrada COSTAL ZONE MANAGEMENT \\
\hline \hline
\end{tabular}

\title{
Shallow-water hydrothermal vents in the Azores (Portugal)*
}

\author{
Ruben P. Couto ${ }^{@,}$, a, b; Armindo S. Rodrigues ${ }^{\mathrm{a}, \mathrm{c}}$; Ana I. Neto ${ }^{\mathrm{a}, \mathrm{d}}$
}

\begin{abstract}
The impact of global warming has been a major issue in recent years and will continue increasing in the future. Knowledge about the effects of ocean acidification on marine organisms and communities is crucial to efficient management. Island environments are particularly sensitive to externally induced changes and highly dependent on their coastal areas.

This study summarises the published information on shallow-water hydrothermal vents of the Azores. These environments were reported to exhibit high metal concentration and acidified seawater due to the diffusion of acidic volcanic gases (mainly $\mathrm{CO}_{2}$ ) and a considerable temperature range. In some vents a water input with lower salinity was reported. These conditions result in a depletion of some of the species but can also enhance a diversity gradient between the "unique" shallow marine hydrothermal ecosystems and the surrounding common coastal marine environment, potentiating the co-existence of a high variety of metabolisms and so biodiversity. Metal content on species from vent areas was reported to be associated with volcanic activity and signs of organism's chronic stress seemed to result in modifications on their morphometry and internal composition. Species able to survive at vent conditions are indicated as potential sentinels for studying the effects of increasing temperature and acidification on marine organisms and as bioindicators of metal accumulation studies at the Azores.

Further information on $\mathrm{CO}_{2}$ flux, metals concentration in the sediments and seawater and on the geochemistry of fluids from active shallow-water hydrothermal systems is needed. Also, research on the productivity of shallowwater vent areas at the Azores and on food chains and interactions between trophic levels at these environments is recommended as it will contribute to a better knowledge of metal bioavailability, accumulation and biomagnification. This research should be complemented by investigations directed to the venting periodicity and episodicity and metal deposits resulting from hydrothermalism. This would increase the value of the Azorean vents as natural laboratories to the implementation of multidisciplinary research aimed at contributing to predict and/or to infer about ocean acidification effects on marine organisms and communities.
\end{abstract}

Keywords: Temperature; Acidification; Submarine degassing; Volcanic gas; Hydrothermal system.

\footnotetext{
@ Corresponding author to whom correspondence should be addressed: Couto <coutoruben@uac.pt>

${ }^{\mathrm{a}}$ Universidade dos Açores, Departamento de Biologia, Rua da Mãe de Deus, 9501-801 Ponta Delgada, Portugal.

b CIIMAR/CIMAR- Centro Interdisciplinar de Investigação Marinha e Ambiental, Universidade do Porto, Rua dos Bragas, 289, 4050-123 Porto, Portugal.

${ }^{c}$ CVARG - Centro de Vulcanologia e Avaliação de Riscos Geológicos, Universidade dos Açores, Rua da Mãe de Deus, 9501-801 Ponta Delgada, Portugal.

d cE3c - Centre for Ecology, Evolution and Environmental Changes/ Azorean Biodiversity Group and Universidade dos Açores, Departamento de Biologia, 9501-801 Ponta Delgada, São Miguel, Azores, Portugal.
}

* Submission: 6 FEB 2015; Peer review: 17 MAR 2015; Revised: 30 APR 2015; Accepted: 3 JUN 2015; Available on-line: 5 JUN 2015

This article contains supporting information online at http://www.aprh.pt/rgci/pdf/rgci-584_Couto_Supporting-Information.pdf
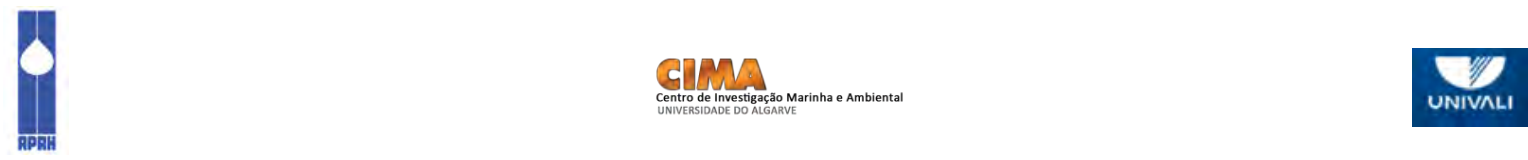


\section{RESUMO}

Fontes hidrotermais de superficie nos Açores (Portugal)

O impacte do aquecimento global é atualmente um assunto de grande interesse e que continuará a aumentar no futuro. O conhecimento sobre os efeitos da acidificação dos oceanos nos organismos e comunidades marinhas é fundamental para uma gestão eficiente. Os ambientes insulares são particularmente sensíveis às mudanças externamente induzidas e muito dependentes das suas áreas costeiras.

Este estudo resume as informações publicadas em fontes hidrotermais de superfície dos Açores. Nestes ambientes foram reportadas elevadas concentrações de metais, água do mar acidificada devido à difusão de gases vulcânicas ácidas (principalmente $\mathrm{CO}_{2}$ ) e um intervalo de temperatura abrangente. Em algumas fontes foi relatada uma entrada de água com baixa salinidade. Estas condições resultam na depleção de algumas das espécies, mas também podem induzir um gradiente de diversidade entre os ecossistemas hidrotermais marinhos de superficie "únicos" do ambiente costeiro marinho comum circundante, potenciando a coexistência de uma elevada variedade de metabolismos e assim a biodiversidade. A concentração de metais em espécies de fontes hidrotermais foi reportada sendo associada à atividade vulcânica e os sinais de stress crónico dos organismos parece resultar em modificações na sua morfometria e composição interna. Espécies capazes de sobreviver em fontes hidrotermais de superficie são indicadas como potenciais indicadores para estudar os efeitos do aumento da temperatura e da acidificação em organismos marinhos e como bioindicadores de acumulação de metal em estudos nos Açores.

É necessário maior conhecimento sobre o fluxo de $\mathrm{CO}_{2}$, a concentração de metais nos sedimentos e na água do mar e sobre a geoquímica de fluidos de sistemas hidrotermais de superfície ativos. Para além disso, a investigação sobre a produtividade em áreas de fontes hidrotermais de superficie nos Açores, nas cadeias alimentares e interações entre níveis tróficos nestes ambientes é recomendada, pois irá contribuir para um melhor conhecimento da biodisponibilidade, acumulação e biomagnificação de metais. Esta investigação deverá ser complementada por investigações dirigidas à periodicidade e sazonalidade das fontes hidrotermais de superfície, assim como aos depósitos de metais resultantes do hidrotermalismo. Isso aumentaria o valor das fontes hidrotermais de superfície dos Açores como laboratórios naturais para a realização de investigação multidisciplinar que visa contribuir para prever elou para inferir sobre os efeitos da acidificação dos oceanos nos organismos e comunidades marinhas.

Palavras-chave: Temperatura; Acidificação; Desgaseificação submarina; Gases vulcânicos; Sistemas hidrotermais.

\section{Introduction}

The Azores archipelago comprises nine volcanic islands (Fig. 1), located in the North Atlantic Ocean where the Eurasian, American and African lithospheric plates meet at a triple junction (Searle, 1980), between latitudes $36^{\circ} 55^{\prime} \mathrm{N}$ and $39^{\circ} 45^{\prime} \mathrm{N}$ and the longitudes $24^{\circ} 45^{\prime} \mathrm{W}$ and $31^{\circ} 17^{\prime} \mathrm{W}$ (Instituto Hidrográfico, 2000). It extends for more than $480 \mathrm{~km}$ along an Northwest-Southeast trend (Morton et al., 1998) and occupies an area of about $2344 \mathrm{~km}^{2}$ (Instituto Hidrográfico, 2000).

The main tectonic features are the Mid-Atlantic Ridge (MAR) that crosses the archipelago between the islands of Flores and Faial, the East Azores Fracture Zone (EAFZ), which extends E-W from the MAR to Gibraltar including the Gloria Fault, and the Terceira Rift (TR), which trends NW-SE from the MAR to the island of Santa Maria (França et al., 2003; Cruz \& França, 2006). On account of this complex tectonic setting, seismic and volcanic activities are frequent throughout the archipelago (França et al., 2003; Ferreira et al., 2005; Viveiros et al., 2010).

Present-day volcanic activity in the Azores is marked by highly active fumarolic fields, hot springs and soils diffuse degassing phenomena (Ferreira et al., 2005), where degassing areas are related to hydrothermal systems (Ferreira, 1994) and anomalous $\mathrm{CO}_{2}$ fluxes are mainly controlled by tectonic structures and by the geomorphology of the volcanic complex (Viveiros et al., 2010).
A striking feature of these islands, as a result of their volcanic nature, is the presence of active deep sea and shallow-water hydrothermal activity caused by diffuse degassing from submerged soils (Cruz, 2003; Ferreira et al., 2005). Organisms associated to hydrothermal activity are chronically exposed to extreme environments characterized by "natural thermal pollution", high metal concentrations (Cunha et al., 2007; Cunha et al., 2008; Wallenstein et al., 2009a; Couto et al., 2010; Dionísio et al., 2013; Wallenstein et al., 2013), either in the form of particles or associated with gases from volcanic emissions (Hansell et al., 2006), as well as acidic seawater due to the diffusion of volcanic gases (Cruz \& França, 2006).

The terrestrial volcanic systems have been well-studied, both because of the long history of devastation caused by their eruptions and because of their geothermal potential (Ferreira, 1994; Cruz et al., 1999; Ferreira \& Oskarsson, 1999; Cruz, 2003; França et al., 2003; Ferreira et al., 2005; Cruz \& França, 2006; Viveiros et al., 2008; Cruz et al., 2010; Viveiros et al., 2010).

The shallow submarine parts of the volcanic system have received relatively little attention, and are poorly studied when compared to some of the mid-ocean ridge systems (Bachraty et al., 2009). Shallow-water venting extends from the intertidal down to more than $200 \mathrm{~m}$ in depth and is, in general, typically characterized by free gas release and water efflux (Dando et al., 1995). At the Azores shallow-water vents occur along the islands and in seamounts (see Fig. 1). A detailed discussion of the 


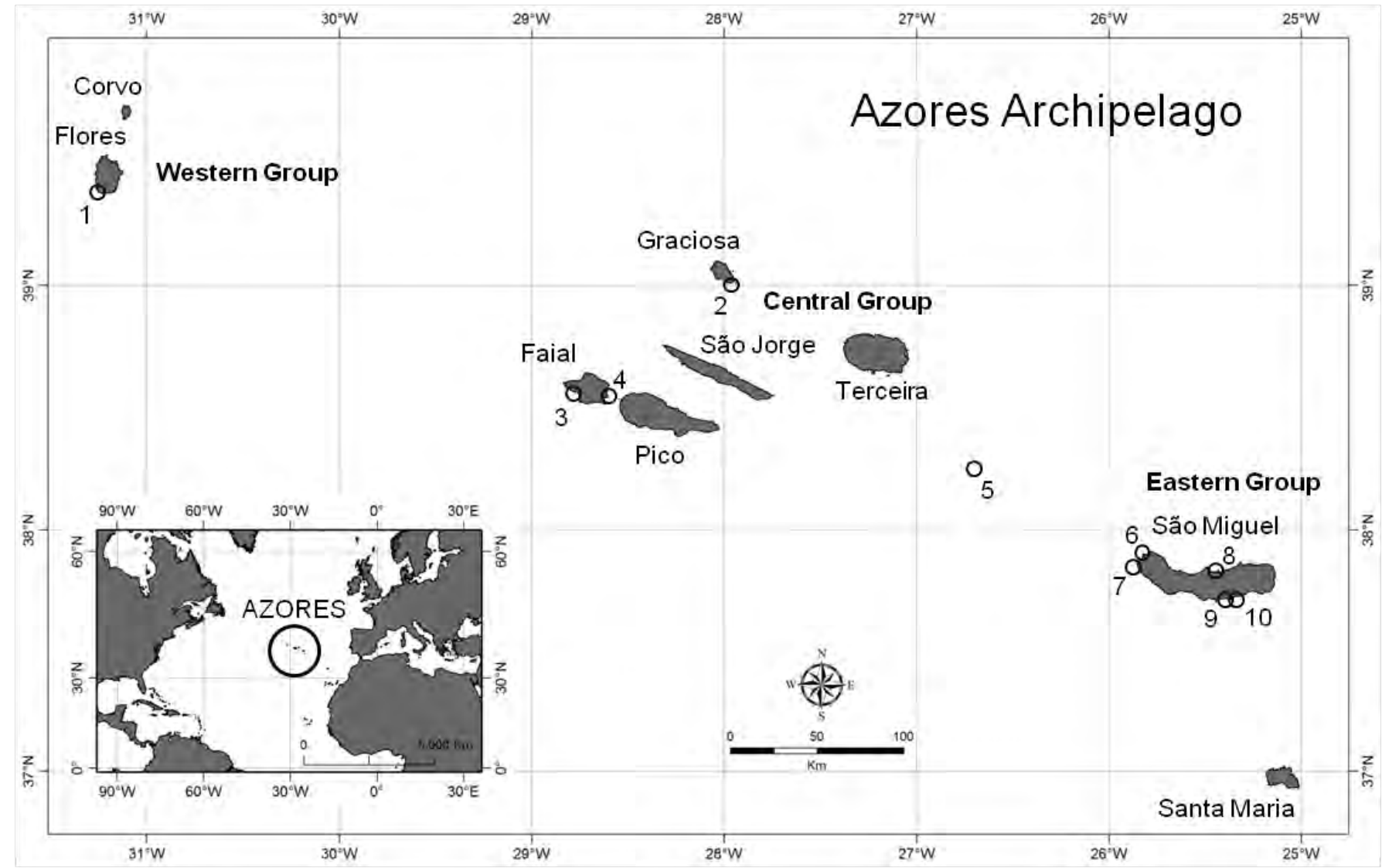

Figure 1 - Azores archipelago, showing the known shallow-water hydrothermal vents locations: (1) Lajedo; (2) Carapacho; (3) Varadouro; (4) Espalamaca; (5) D. João de Castro Bank; (6) Mosteiros (Beach); (7) Ferraria; (8) Porto Formoso; (9) Ribeira Quente (Lobeira); (10) Ribeira Quente (Beach).

Figura 1 - Arquipélago dos Açores com a localização das fontes hidrotermais de superfície conhecidas: (1) Lajedo; (2) Carapacho; (3) Varadouro; (4) Espalamaca; (5) Banco D. João de Castro; (6) Mosteiros (Praia); (7) Ferraria; (8) Porto Formoso; (9) Ribeira Quente (Lobeira); (10) Ribeira Quente (Praia).

differences between shallow-water and deep sea hydrothermal vent ecosystems is given by Tarasov et al. (2005). Temperatures at shallow vents, due to the lower boiling point, are not as high as in the widely-studied deep sea vents, which can exceed $277^{\circ} \mathrm{C}$ (Desbruyéres et al., 2001). Primary production at shallow depths is mainly generated by photosynthesis, while at deep-sea vents it is generated by chemoautotrophic or methanotrophic microbes (Tarasov et al., 2005).

In order to increase knowledge and better understand the functioning and the processes occurring at these peculiar systems, different types of studies, with different aims and methodologies, have been published in a variety of scientific journals. This review, aimed at congregating the dispersed published information on shallowwater hydrothermal vents at the Azores, summarises the current published information on those systems since 1985.

\section{Hydrothermal areas}

Degassing areas in the Azores are related to hydrothermal systems (Ferreira et al., 2005). Active shallow- water hydrothermal vent fields are found at the islands of Flores, Faial, Graciosa, São Miguel and at D. João de Castro Bank

D. João de Castro Bank is one of the best studied sites. It is the remains of an island formed by a submarine eruption in 1720 (Daussy, 1830; Agostinho, 1941; Oliveira, 1943) that disappeared in 1722 (Daussy, 1830). Back then the hydrothermal activity was already reported by navigators (Daussy, 1830; Agostinho, 1941; Oliveira, 1943) but only in 1941 the exact location of the bank was definitively established (Oliveira, 1943). This is one of the few Azorean vents that is not near any island shore, lying 36 nautical miles away from Terceira and 40 miles away from São Miguel islands (Santos et al., 2001).

The majority of the other known vents in the Azores are located near or in the islands shores and are variable in shore height, depth, substratum composition and exposition (Table 1). Even vents at the same island or at the same area can have different physical and chemical conditions. Some, e.g. Ferraria, Varadouro, Lajedo and Carapacho are known by their thermal baths. On São 
Table 1 - Shallow-water hydrothermal vent sites studied in the Azores.

Tabela 1 - Fontes hidrotermais de superfície estudadas nos Açores.

\begin{tabular}{|c|c|c|c|c|c|}
\hline Local & Island & $\begin{array}{l}\text { GPS Coordi- } \\
\text { nates }\end{array}$ & Depth (m) & Seafloor & References \\
\hline $\begin{array}{l}\text { D. João de } \\
\text { Castro Bank }\end{array}$ & - & $\begin{array}{l}\text { N } 38^{\circ} 13^{\prime} 59^{\prime \prime} \\
\text { W } 26^{\circ} 37^{\prime} 59^{\prime \prime}\end{array}$ & $18-45$ & Rock & $\begin{array}{l}\text { Aguiar \& Costa, 2010; Ávila, 1997; 2007; } \\
\text { Ávila et al., 2004; 2007; Boury-Esnault \& } \\
\text { Lopes, 1985; Cardigos et al., 2002; 2004; } \\
\text { 2005; Cardigos, 2002; 2006; Colaço et al., } \\
\text { 2006; D’Udekem d'Acoz \& Wirtz, 1999; } \\
\text { MBL, 2009; Mohandass et al., 2012; } \\
\text { Raghukumar et al., 2008; Santos et al., 1996; } \\
\text { 2001; 2010; Sobrinho-Gonçalves \& Cardigos, } \\
\text { 2006 }\end{array}$ \\
\hline Lajedo & Flores & $\begin{array}{l}\text { N } 39^{\circ} 22^{\prime} 58^{\prime \prime} \\
\text { W } 31^{\circ} 15^{\prime} 11^{\prime \prime}\end{array}$ & Intertidal & Rock & Aguiar \& Costa, 2010; MBL, 2009 \\
\hline Espalamaca & Faial & $\begin{array}{l}\text { N } 38^{\circ} 32^{\prime} 44^{\prime \prime} \\
\text { W } 28^{\circ} 36^{\prime} 10^{\prime \prime}\end{array}$ & $5-50$ & Sand & $\begin{array}{l}\text { Aguiar \& Costa, 2010; MBL, 2009; Munaro et } \\
\text { al., } 2010\end{array}$ \\
\hline Carapacho & Graciosa & $\begin{array}{l}\text { N } 39^{\circ} 00^{\prime} 45^{\prime \prime} \\
\text { W } 27^{\circ} 57^{\prime} 32^{\prime \prime}\end{array}$ & Intertidal & $\begin{array}{l}\text { Rock and } \\
\text { Boulders }\end{array}$ & Aguiar \& Costa, 2010; MBL, 2009 \\
\hline Varadouro & Faial & $\begin{array}{l}\text { N } 38^{\circ} 33^{\prime} 51^{\prime \prime} \\
\text { W } 28^{\circ} 45^{\prime} 35^{\prime \prime}\end{array}$ & Intertidal & $\begin{array}{l}\text { Rock and } \\
\text { Boulders }\end{array}$ & Aguiar \& Costa, 2010; MBL, 2009 \\
\hline $\begin{array}{l}\text { Mosteiros } \\
\text { (Beach) }\end{array}$ & São Miguel & $\begin{array}{l}\text { N } 37^{\circ} 53^{\prime} 12^{\prime \prime} \\
\text { W } 25^{\circ} 49^{\prime} 26^{\prime \prime}\end{array}$ & Intertidal & Sand & Aguiar \& Costa, 2010; MBL, 2009 \\
\hline Ferraria & São Miguel & $\begin{array}{l}\text { N } 37^{\circ} 51^{\prime} 30^{\prime \prime} \\
\text { W } 25^{\circ} 51^{\prime} 07^{\prime \prime}\end{array}$ & Intertidal & Rock & $\begin{array}{l}\text { (Aguiar, 1999; 2005; Aguiar \& Costa, 2010; } \\
\text { Albuquerque et al., 2002; Carvalho et al., } \\
\text { 2009; 2011; Cruz et al., 2010; Cunha et al., } \\
\text { 2008; Freire, 2006; MBL, 2009; Moore et al., } \\
\text { 1995; Vedel \& Depledge, 1995; Wallenstein } \\
\text { et al., 2009a; 2009b; 2013; Weeks et al., } 1995\end{array}$ \\
\hline $\begin{array}{l}\text { Ribeira Quente } \\
\text { (Lobeira) }\end{array}$ & São Miguel & $\begin{array}{l}\text { N } 37^{\circ} 43^{\prime} 26^{\prime \prime} \\
\text { W } 25^{\circ} 19^{\prime} 09^{\prime \prime}\end{array}$ & $6-8$ & $\begin{array}{l}\text { Rock and } \\
\text { Sand }\end{array}$ & $\begin{array}{l}\text { (Aguiar, 1999; 2005; Aguiar \& Costa, 2010; } \\
\text { Dionísio et al., 2013; MBL, 2009; Mendes, } \\
\text { 2008; Zillig et al., 1990; 1991 }\end{array}$ \\
\hline $\begin{array}{l}\text { Ribeira Quente } \\
\text { (Beach) }\end{array}$ & São Miguel & $\begin{array}{l}\text { N } 37^{\circ} 43^{\prime} 46^{\prime \prime} \\
\text { W } 25^{\circ} 18^{\prime} 30^{\prime \prime}\end{array}$ & Intertidal & Sand & $\begin{array}{l}\text { (Aguiar, 1999; 2005; Aguiar \& Costa, 2010; } \\
\text { Ávila et al., 2007; Cunha et al., 2008; Huber } \\
\text { et al., 1986; Manaia \& Costa, 1991; Manaia et } \\
\text { al., 1994; MBL, 2009; Nunes et al., 1992; } \\
\text { Segerer } \text { et al., 1991 }\end{array}$ \\
\hline Porto Formoso & São Miguel & $\begin{array}{l}\text { N } 37^{\circ} 49^{\prime} 18.8^{\prime \prime} \\
\text { W } 25^{\circ} 27^{\prime} 25.2^{\prime \prime}\end{array}$ & Intertidal & Boulders & $\begin{array}{l}\text { (Aguiar \& Costa, 2010; Couto et al., 2010; } \\
\text { 2012; Wallenstein et al., 2009a; } 2013\end{array}$ \\
\hline
\end{tabular}

Miguel Island, the vent sites Mosteiros, Ferraria, Ribeira Quente and Porto Formoso are in intertidal areas used by locals for leisure.

Only two studies have been published on habitat mapping of Azorean hydrothermal vent fields. Santos et al. (2001) presented bathymetric maps and a general characterization of the D. João de Castro bank. Munaro et al. (2010) mapped the shallow-water hydrothermal vent site of Espalamaca.

Seven of the Azorean vent sites are located within areas subjected to some environmental protection, either within the Island Park delineation (e.g., Ferraria and Carapacho) or within the Azores Marine Park domain (e.g., D. João de Castro Bank). D. João de Castro seamount was classified as a Special Area of Conservation (SAC) and as a sensitive habitat under the "Submarine structures made by leaking gases". Espalamaca de- gasification low temperature hydrothermal field is also integrated in a larger protected area designated Baixa do Sul, recently classified as a SAC and integrated in the Faial's Natural Park (Aguiar \& Costa, 2010).

Lagedo (Flores), Carapacho (Graciosa), Ferraria (S. Miguel) and Ladeira da Velha (S. Miguel) were previously classified as Important Bird Areas (IBAs) and now Ferraria, Mosteiros, and Ladeira da Velha (Porto Formoso) on S. Miguel Island, as well as Espalamaca (Faial) are classified as Protected Areas for Resources Management within the framework of the respective Island Park premises (Aguiar \& Costa, 2010). Carapacho (Graciosa) and Lagedo (Flores) are classified as Protected Areas for Habitat or Species Management. The marine hydrothermal site of Varadouro (Faial) and Ribeira Quente (S. Miguel) are not included within the respective Islands Park limits (Aguiar \& Costa, 2010). 
However, these protection figures were not established to value and protect the hydrothermal ecosystems, but to protect other coastal systems and organisms (Aguiar $\&$ Costa, 2010). In fact, there aren't clear indications of the uses and restrictions of the shallow marine hydrothermal sites. This information, however, should be provided and complemented with management plans for each area.

\section{Hydrothermal fluids}

\subsection{Gas composition of fluids}

Data on the gas composition of shallow submarine hydrothermal vents in the Azores is only available for D. João de Castro Bank (Cardigos et al., 2005). Although there is no gas flux evaluation, the authors reported that the major gas component was $\mathrm{CO}_{2}(90 \%)$, with lesser $\mathrm{H}_{2} \mathrm{~S}$ (9-36 ppm), $\mathrm{H}_{2}$ (19-21749 ppm), $\mathrm{CH}_{4}$ (0.0-84.2 $\mathrm{ppm}$ ) and the presence of He (Santos et al., 1996; Cardigos et al., 2005).

\subsection{Water fluxes and solutes}

Water fluxes are formed by the venting of meteoric and seawater, which composition has been altered as a result of interactions with the sediments by elevated temperatures and the entrainment of interstitial waters by the rising fluids. Rising gas bubbles can initiate water circulation within the sediment, so that the released water is recharged by overlying water ( $\mathrm{O}^{\prime} \mathrm{Hara}$ et al., 1995; Dando et al., 1999). Reports on this matter are restricted to D. João de Castro Bank and indicate flow rates of venting water of 773 and $787 \mathrm{~mL} / \mathrm{min}$ in September 1999 (Cardigos et al., 2005). This work is an important milestone for shallow-water hydrothermal vent studies in the Azores as it provides information on water chemistry from shallow-water hydrothermal vents and a physical characterization of the vent surroundings. It distinguishes two main types of vents: "white" vents (due to the presence of a white bacterial mat, mainly an attached form of Beggiatoa TREVISAN) and "yellow" vents (due to an amorphous material bordering the vents with no evidence for crystalline mineral phases), characterized by different physical and chemical properties (Cardigos et al., 2005).

Further research on the subject is restricted to the collection of physical and chemical data from several vents performed in the course of the International Census of Marine Microbes (ICoMM), and made available online (MBL, 2009).

Available data on temperatures at the fluid outlets and other physical and chemical parameters of shallow submarine vents in the Azores revealed that they are very variable [Supplementary Information - Annex I] and for same cases, different from the surrounding seawater environment (e.g. pH) (Instituto Hidrográfico, 2000).
Vents at the same island or at the same area have different physical and chemical parameters. This represents one of the characteristics of shallow water hydrothermal vents: their singularity (therefore unreplicated). Each vent is associated to a specific substratum type and depth, and the physical and chemical properties of the fluid can be quite variable (Melwani \& Kim, 2008). Even the temperature range can be of considerable magnitude (Vedel \& Depledge, 1995; Wallenstein et al., 2013). The majority of the data concerns to physical data, revealing the need for more studies regarding chemical water analysis and dissolved gases $\left(\right.$ e.g. $\left.\mathrm{CO}_{2}\right)$.

\section{Biota}

\subsection{Microorganisms}

Microbial investigations on the shallow hydrothermal vents at the Azores were mainly directed to bacteria (Huber et al., 1986; Zillig et al., 1990; Manaia \& Costa, 1991; Segerer et al., 1991; Zillig et al., 1991; Nunes et al., 1992; Manaia et al., 1994; Aguiar, 1999; 2005; Albuquerque et al., 2002; Cardigos, 2002; Cardigos et al., 2004; 2005; Raghukumar et al., 2008; MBL, 2009; Aguiar \& Costa, 2010; Zinger et al., 2011; Mohandass et al., 2012) with the selective isolation of chemosynthetic and thermophilic bacteria (see Table 2). A few studies were devoted to Fungi and Protists (Colaço et al., 2006; Raghukumar et al., 2008).

Huber et al. (1986) described an anaerobic, extremely thermophilic eubacterium (Thermotoga maritime HUBER), isolated from geothermally heated sea floors in Ribeira Quente (SE coast of São Miguel island), representing a new genus and a new species. Segerer et al. (1991) described the bacteria genus Stygiolobus SEGERER from the same location, pointing that "it may be that the genus Stygiolobus is a very rare and possibly even an endemic genus in the Azores". Zillig et al. (1990) isolated and described the metabolism and phylogeny of a hyperthermophilic bacteria from a moderately active submarine hydrothermal area also at Ribeira Quente, at a depth of about $9 \mathrm{~m}, 200 \mathrm{~m}$ away from a steep, rocky shore from São Miguel Island that was later classified as Hyperthermus butylicus ZILLIG (Zillig et al., 1991).

Manaia \& Costa (1991) described the phenotypic characteristics of several bacterial isolates from the same area, demonstrating a relationship, at a low similarity level, between the marine and the terrestrial bacterial strains, suggesting that the exchange of these halotolerant strains between nearby marine and terrestrial hot springs is probably frequent.

The isolation and characterization of Rhodothermus ALFREDSSON strains from shallow marine hot springs at Ribeira Quente was performed by Nunes et al. (1992). Later, Manaia et al. (1994) studied the halotolerant Thermus thermophilus (ex Oshima \& 
Table 2 - Microbial species isolated from hydrothermal sites in the Azores.

Tabela 2 - Espécies microbianas isoladas em locais com atividade hidrotermal nos Açores.

\begin{tabular}{|c|c|}
\hline Species & References \\
\hline \multicolumn{2}{|l|}{ Bacteria } \\
\hline Thermotoga maritime Huber & Huber et al., 1986 \\
\hline Hyperthermus butylicus Zillig & Zillig et al., 1990; 1991) \\
\hline Stygiolobus azoricus Segerer & Segerer et al., 1991 \\
\hline Rhodothermus Alfredsson & Nunes et al., 1992 \\
\hline Thermus thermophiles (ex Oshima \& Imahori) Manaia & Manaia et al., 1994 \\
\hline Albidovulum inexpectatum Albuquerque & Albuquerque et al., 2002 \\
\hline Beggiatoa sp. Trevisan & Cardigos, 2002; 2006; Cardigos et al., 2004; 2005 \\
\hline $\begin{array}{l}\text { Alcaligenes faecalis Castellani \& Chalmers } \\
\text { Bacillus flexus (ex Batchelor) Priest et al. } \\
\text { Bacillus licheniformis (Weigmann) Chester } \\
\text { Bacillus subtilis (Ehrenberg) Cohn } \\
\text { Brevibacterium casei Collins et al. } \\
\text { Halomonas sp. Vreeland et al. emend. Dobson \& Franzmann } \\
\text { Micrococcus luteus (Schroeter) Cohn } \\
\text { Pseudoalteromonas sp. Gauthier et al. emend. Ivanova et al. } \\
\text { Staphylococcus arlettae Schleifer } \text { et al. } \\
\text { Staphylococcus cohnii Schleifer \& Kloos } \\
\text { Staphylococcus succinus Lambert et al. } \\
\text { Yersinia } \text { sp. Loghen }\end{array}$ & Mohandass et al., 2012 \\
\hline \multicolumn{2}{|l|}{ Fungi } \\
\hline $\begin{array}{l}\text { Aspergillus sp. Micheli } \\
\text { Cladosporium sp. Lindau }\end{array}$ & Raghukumar et al., 2008 \\
\hline \multicolumn{2}{|l|}{ Protists } \\
\hline Ulkenia sp. Gaertn & Raghukumar et al., 2008 \\
\hline
\end{tabular}

Imahori) Manaia. These extreme thermophile and halotolerant species indicate a specific capacity of adaptation to the extreme environment (Manaia \& Costa, 1991) that can promote speciation even to Genus level (Huber et al., 1986; Zillig et al., 1990; Segerer et al., 1991; Zillig et al., 1991; Albuquerque et al., 2002).

After the analysis of several bacterial isolates recovered from the marine hot spring of Ferraria by Albuquerque et al. (2002) the new species Albidovulum inexpectatum Albuquerque was proposed.

Aguiar (1999) made a preliminary characterization of intertidal and subtidal microbial communities, complemented with a study on the microbial ecology of Azorean hot springs (Aguiar, 2005). This later work report that microbial communities are very different between sites and that a more continuous sampling effort is necessary to better understand the nature of the microbial community composition in these shallow-water marine vents.

Mohandass et al. (2012) studied the bacterial diversity and their adaptations to the shallow-water hydrothermal vents and reported specific physiological changes that are likely to be adaptations to that environment. These authors alerted to their potential use in biotechnological applications. Specific physiological changes were also reported to other groups like Fungi and Protists (Colaço et al., 2006; Raghukumar et al., 2008)
According to Albuquerque et al. (2002), the water temperature of the vents drops very rapidly in contact with seawater and it is likely that the organisms colonize the geothermal aquifer or the porous lava before the hydrothermal water is released into the seawater. The extreme occurrence of Bacillus sp. found at D. João de Castro Bank was related to the ability of these organisms to form spores, thus enabling them to withstand a wide range of environmental conditions like temperature and pH (Mohandass et al., 2012).

\subsection{Fauna and flora}

Different approaches have been made to the study of the fauna and flora of the Azorean vents (Table 3) but, in general, these organisms are similar to those of other coastal and seamount areas of the archipelago (Cardigos et al., 2005).

Ávila (1997) published a list of the marine molluscs collected at $30 \mathrm{~m}$ depth at D. João de Castro Bank. D'Udekem d'Acoz \& Wirtz (1999) published a list of animal species identified at the same area and commented that the studied area was "impoverished" when compared to other sites at similar depths, probably due to the "toxic environment" of the vent. A similar comment was made by Ávila et al. (2004) when comparing marine molluscs composition between shallow-water hydrothermal vent sites with other sites at similar 
Table 3 - Taxonomic groups studied at shallow-water hydrothermal vents in the Azores.

Tabela 3 - Grupos taxonómicos estudados em fontes hidrotermais de superficie nos Açores.

\begin{tabular}{|c|c|}
\hline $\begin{array}{l}\text { Taxonomic } \\
\text { Group }\end{array}$ & References \\
\hline Algae & $\begin{array}{l}\text { Ávila et al., 2004; Cardigos, 2002; Cardigos et al., 2004; 2005; Colaço et al., 2006; Couto et al., 2010; Santos et al., } \\
\text { 1996; Wallenstein et al., 2009a; 2009b; } 2013\end{array}$ \\
\hline Porifera & $\begin{array}{l}\text { Boury-Esnault \& Lopes, 1985; Cardigos et al., 2004; 2005; Cardigos, 2002; Colaço et al., 2006; D'Udekem d'Acoz } \\
\text { \& Wirtz, 1999; Santos et al., 1996) }\end{array}$ \\
\hline Bryozoa & Cardigos et al., 2004; Cardigos, 2002; Santos et al., 1996 \\
\hline Cnidaria & Cardigos, 2002; Cardigos et al., 2004; 2005; d’Acoz \& Wirtz, 1999; Santos et al., 1996) \\
\hline Ctenophora & Cardigos, 2002; Cardigos et al., 2004; 2005; d'Acoz \& Wirtz, 1999) \\
\hline Annelida & Cardigos, 2002; Cardigos et al., 2004; 2005; d’Acoz \& Wirtz, 1999; Santos et al., 1996; Colaço et al., 2006 \\
\hline Arthropoda & $\begin{array}{l}\text { Cardigos, 2002; Cardigos et al., 2004; 2005; d'Acoz \& Wirtz, 1999; Santos et al., 1996; Dionísio et al., 2013; Moore } \\
\text { et al., 1995; Weeks et al., 1995) }\end{array}$ \\
\hline Echinodermata & Cardigos, 2002; Cardigos et al., 2004; 2005; d'Acoz \& Wirtz, 1999; Santos et al., 1996; \\
\hline Diatoms & Colaço et al., 2006; Raghukumar et al., 2008 \\
\hline Mollusca & $\begin{array}{l}\text { Ávila, 1997; 2007; Ávila et al., 2004; 2007; Cardigos, 2002; Couto et al., 2012; Cunha et al., 2008; d'Acoz \& Wirtz, } \\
\text { 1999; Santos et al., 1996; Vedel \& Depledge, 1995) }\end{array}$ \\
\hline Tunicata & Cardigos et al., 2004; Cardigos, 2002; d'Acoz \& Wirtz, 1999) \\
\hline Pisces & $\begin{array}{l}\text { Cardigos et al., 2004; Cardigos, 2002; d'Acoz \& Wirtz, 1999; Santos et al., 1996; Sobrinho-Gonçalves \& Cardigos, } \\
\text { 2006) }\end{array}$ \\
\hline Reptilia & Cardigos, 2002; Cardigos et al., 2004 \\
\hline Aves & Cardigos, 2002; Cardigos et al., 2004 \\
\hline Mamalia & Cardigos, 2002; Cardigos et al., 2004 \\
\hline Meiobenthos & Mendes, 2008 \\
\hline
\end{tabular}

depths. Further research by the same authors (Ávila et al., 2007) revealed differences not only in terms of presence/absence, but also in species densities with a lower number of species and lower densities at the studied hydrothermal vents sites.

A comparative study between meiobenthic communities affected by hydrothermal activity and a control site without such influence (Mendes, 2008), concluded that the hydrothermal site has more or less the same composition as non-hydrothermal sites but with lower abundances.

Recently, Wallenstein et al. (2013) gave an account of the habitat characteristics and associated intertidal seaweed communities subjected to shallow-water hydrothermal activity in the Azores. Seaweed communities were found to be species poor and to have a disproportionally larger number of filamentous early successional species. The authors pointed to the remarkable ecological resemblance between the studied communities and those affected by an acid mine drainage in the UK. Their study suggested that hydrothermalism could be a useful scenario for pollution studies under conditions of ocean warming and acidification.

\section{Vent effects on the biota}

Moore et al. (1995) and Vedel \& Depledge (1995), analysed the copper $(\mathrm{Cu})$ and zinc $(\mathrm{Zn})$ concentrations on, respectively amphipods and limpets living on hydrothermal vents. Moore et al. (1995), analysing the whole body concentration, found a general increase of $\mathrm{Cu}$ and $\mathrm{Zn}$ concentrations in four species of talitroid amphipods, remaining to be shown whether this is a species characteristic, or an effect resulting from the volcanic origin of the islands. Vedel \& Depledge (1995) found that the essential trace metals, $\mathrm{Cu}$ and $\mathrm{Zn}$ (important cofactors in the functioning of many enzymes), occurred at significantly higher concentrations in the tissues of limpets from the thermal vent population, consistent with the higher enzymic concentrations found in organisms as result of metabolic adaptive responses to high temperatures. These later authors examined intraspecific differences in thermal tolerance in different populations of marine snails and limpets from rocky shores and from the vicinity of a thermal vent and verified that there was a tendency for a greater thermal tolerance in individuals from the hot spring site.

Cunha et al. (2008), in a study aimed to evaluate the bioavailability of metals in the Macaronesian endemic limpet Patella candei gomesii DROUET living close to shallow-water hydrothermal vents, reported modifications in the organisms morphometry, higher metal concentrations ( $\mathrm{Cs}, \mathrm{Co} \mathrm{Cu}, \mathrm{Mn}, \mathrm{Rb}$, and $\mathrm{Zn}$ ), and more prevalent apoptotic nuclei. Abnormal shells on limpets living at intertidal hydrothermal vents were also found 
by (Couto et al., 2012) as a result of the higher acidity of the vent locations, providing evidences that limpets are sensitive to such environmental changes and therefore have an enormous potential to be used as sentinel organisms of ocean acidification.

Trace metal bioavailability evaluation on barnacles (Chthamalus stellatus POLI) by Weeks et al. (1995) revealed high levels of $\mathrm{Zn}$ and $\mathrm{Cd}$ in the organisms from the Ferraria vent.

Colaço et al. (2006), in a study aimed at evaluating trace metal concentrations in species of macroalgae and sponges and the tolerance of microorganisms (protists and bacteria) to trace metals, produced baseline data on metal content for the studied organisms and concluded they were well adapted to the metal enriched waters of the study site (D. João de Castro).

Wallenstein et al. (2009a) compared the accumulation of a selected pool of chemical elements by common intertidal macroalgae from three distinct situations acting on rocky shore locations around São Miguel Island: pristine shores, urbanized coasts, and coasts subjected to shallow-water hydrothermal activity. Results revealed that the algae from the hydrothermally active had higher concentrations of the metals $\mathrm{Mn}, \mathrm{Rb}$ and $\mathrm{Zn}$, indicating these organisms could be used as bioindicators of heavy metal enrichment. A subsequent research by the same authors (Wallenstein et al., 2009b), studied the effect of exposure time on the bioaccumulation of certain elements by Cystoseira abies-marina (GMELIN) AGARDH specimens subjected to shallowwater hydrothermal activity and concluded that this species could be used as a tool to monitor water quality in the Azores. High levels of metal accumulation ( $\mathrm{Zn}$, $\mathrm{Rb}$ and $\mathrm{Mn}$ ) and morphometric changes were also reported by Couto et al. (2010) for the calcareous alga Corallina elongata ELLIS ET SOLANDER from shallow vents.

\section{Conclusions and directions for future research}

Research on shallow-water hydrothermal vents confirmed that organisms that live in such environments as hydrothermal vents are chronically exposed to "natural thermal pollution", high metal concentration (Hansell et al., 2006), as well as to acidified seawater adjacent to hydrothermally active areas due to the diffusion of acidic volcanic gases (mainly $\mathrm{CO}_{2}$ ) (Cruz \& França, 2006). In some of the shallow vents a water input with lower salinity was reported (Dando et al., 1995; Dando et al., 1999; Biasi et al., 2004) (see Table 2). In Ladeira da Velha a freshwater input (small stream) is visible running from land to the seawater (Couto et al., 2010; Couto et al., 2012). Extreme environments can result in a depletion of some of the species present in the surrounding areas, except the ones that exhibit some tolerance to extreme conditions (Melwani \& Kim, 2008), which is reflected in differences on species number and abundances (D'Udekem d'Acoz \& Wirtz, 1999; Ávila et al., 2004; Ávila et al., 2007; Mendes, 2008).

Research has also documented that organisms can develop physiological adaptations in extreme environments (Manaia \& Costa, 1991; Vedel \& Depledge, 1995; Cardigos et al., 2006; Raghukumar et al., 2008; Couto et al., 2010; Mohandass et al., 2012). Metal content on species from vent areas was reported to be associated with volcanic activity (Cardigos et al., 2005; Colaço et al., 2006; Cunha et al., 2008; Wallenstein et al., 2009a; Wallenstein et al., 2009b), and the species able to survive at those conditions are indicated as potential useful bioindicators for metal accumulation studies at the Azores (Cunha et al., 2008; Wallenstein et al., 2009b; Couto et al., 2010; Couto et al., 2012). Calcareous organisms (e.g. coralline algae, corals, echinoderms or molluscs, among others), chronically exposed to conditions that promote the dissolution of their calcified structures/ components were indicated as potential sentinel species for studying the effects of increasing temperature and acidification on marine organisms (Hall-Spencer et al., 2008; Marshall et al., 2008; Martin et al., 2008; Couto et al., 2010; Couto et al., 2012). These findings are particularly important in recent times when ocean acidity is becoming a major concern (HallSpencer et al., 2008; Marshall et al., 2008; Martin et al., 2008; Riebesell, 2008; Riebesell et al., 2010).

Available data on the fluid analysis (Cardigos et al., 2005; Cruz \& França, 2006) (see Annex I [Supplementary Information / Informação Suplementar]), is insufficient and further information is needed on metals concentration in the sediments and seawater and on the geochemistry of fluids from active shallow-water hydrothermal systems. Particle and fluid fluxes, especially $\mathrm{CO}_{2}$ flux, which has implications on acidity, also deserve attention.

Research on the productivity of shallow-water vent areas at the Azores and on food chains and interactions between trophic levels at these environments will contribute to a better knowledge of metal bioavailability, accumulation and biomagnification. This research should be complemented by investigations directed to the venting periodicity and episodicity and metal deposits resulting from hydrothermalism.

The signs of chronic stress reported for some organisms from the studied shallow-water hydrothermal vents (Colaço et al., 2006; Cunha et al., 2008; Mendes, 2008; Raghukumar et al., 2008; Couto et al., 2010; Couto et al., 2012; Mohandass et al., 2012) seems to result in modifications on their morphometry and internal composition that can promote speciation (Huber et al., 1986; Zillig et al., 1990; Segerer et al., 1991; Zillig et al., 1991; Albuquerque et al., 2002). The ways or tools 
that organisms found in order to survive in extreme environments should be explored by biotechnology.

In conclusion, a review of the available published information made in the present study reveals that, despite all what has been done, a deeper knowledge is needed, encompassing a better characterization, of the vents and organisms living there, complemented by accurate maps. This would establish a baseline for the urgently needed effort that should be done to create specific protection figures to all Azorean shallow marine hydrothermal ecosystems and their surroundings. This would increase the value of the Azorean vents as natural laboratories to the implementation of multidisciplinary research aimed at contributing to predict and/or to infer about ocean acidification effects on marine organisms and communities.

\section{Appendix}

Supporting Information associated with this article is available on-line at http://www.aprh.pt/rgci/pdf/rgci584_Couto_Supporting-Information.pdf

\section{Acknowledgments}

The authors thank Francisco M. Wallenstein for helpful comments and an English revision of the manuscript. This research was partially supported by the European Regional Development Fund (ERDF) through the COMPETE - Operational Competitiveness Programme and national funds through FCT - Foundation for Science and Technology, under the project "PEstC/MAR/LA0015/2013. It was also partly supported by cE3c Unit FCT funding (Ref: UID/BIA/00329/2013), CIRN (Centro de Investigação de Recursos Naturais, University of the Azores), and CIIMAR (Interdisciplinary Centre of Marine and Environmental, Porto, Portugal). Ruben Couto was supported by a Post-Doctoral funding (M3.1.7/F/006/2011) granted by FRC - Fundo Regional da Ciência (SRECC - Secretaria Regional da Educação, Ciência e Cultura, Regional Government of the Azores).

\section{References}

Agostinho, J. (1941) - A erupção submarina de 1720 entre a Terceira e São Miguel. Açoreana, (ISSN: 0874-0380), 2(4):268275, Sociedade Afonso Chaves, Porta Delgada, Açores, Portugal.

Aguiar, P.C.B. (1999) - Ecologia Microbiana de fontes hidrotermais em São Miguel. 54p., Biology Degree, Universidade dos Açores, Ponta Delgada. Unpublished.

Aguiar, P.C.B. (2005) - Microbial ecology of Azorean hot springs revealed by culture and molecular techniques. 270p., PhD thesis, Portland State University, Portland, Oregon, USA. Unpublished.

Aguiar, P.C.B.; Costa, A.C. (2010) - Shallow hydrothermal vents and marine protected areas within the Azores archipelago. In: $\mathrm{H}$. Calado \& A. Gil (Eds.), Geographic Technologies applied to Marine Spatial Planning and Integrated Coastal Zone Management, pp.10-14, Geographic Information and Land Planning Research Center (CIGPT), University of the Azores. Ponta Delgada, Portugal. ISBN: 978-972-8612-64-1. Available on-line at http://repositorio.uac.pt/handle/10400.3/569

Albuquerque, L.; Santos, J.; Travassos, P.; Nobre, M.F.; Rainey, F.A.; Wait, R.; Empadinhas, N.; Silva, M.T.; Costa, M.S. (2002) - Albidovulum inexpectatum gen. nov., sp. nov., a nonphotosynthetic and slightly thermophilic bacterium from a marine hot spring that is very closely related to members of the photosynthetic genus Rhodovulum. Applied and Environmental Microbiology, 68(9):4266-4273. DOI: 10.1128/AEM.68.9.4266-4273.2002.

Ávila, S. (1997) - Moluscos marinhos recolhidos no Banco D. João de Castro. Açoreana, (ISSN: 0874-0380), 8(3):404-405, Sociedade Afonso Chaves, Porta Delgada, Açores, Portugal.

Ávila, S.P.; Cardigos, F.; Santos, R.S. (2004) - D. João de Castro Bank, a shallow water hydrothermal-vent in the Azores: checklist of the marine molluscs. Arquipélago. Life and Marine Sciences, (ISSN: 0873-4704), 21A:75-80. Available on-line at http://www.horta.uac.pt/intradop/index.php/arquipgo-life-and-marinesciences-topmenu2-198.

Ávila, S.P.; Cardigos, F.; Santos, R.S. (2007) - Comparison of the community structure of the marine molluscs of the "Banco D. João de Castro" seamount (Azores, Portugal) with that of typical inshore habitats on the Azores archipelago. Helgoland Marine Research, 61:43-53. DOI: 10.1007/s10152-006-0052-5.

Bachraty, C.; Legendre, P.; Desbruyères, D. (2009) - Biogeographic relationships among deep-sea hydrothermal vent faunas at global scale. Deep-Sea Research Part I, 56:1371-1378. DOI: 10.1016/j.dsr.2009.01.009.

Biasi, A.M.D.; Bianchi, C.N.; Aliani, S.; Cocito, S.; Peirano, A.; Dando, P.R.; Morri, C. (2004) - Epibenthic communities in a marine shallow area with hydrothermal vents (Milos island, Aegean Sea). Chemistry and Ecology, 20(Supplement 1):S89S105. DOI: 10.1080/02757540310001629152.

Cardigos, F.A.D. (2002) - Contribuição para a Implementação de um Plano de Gestão no Sítio de Interesse Comunitário Banco D. João de Castro, Açores. 96 p., MSc thesis, Universidade dos Açores, Angra do Heroísmo, Açores, Portugal. Unpublished.

Cardigos, F.; Colaço, A.; Dando, P.R.; Ávila, S.P.; Sarradin, P.M.; Tempera, F.; Conceição, P.; Pascoal, A.; Santos, R.S. (2005) Shallow water hydrothermal vent field fluids and communities of the D. João de Castro Seamount (Azores). Chemical Geology, 224:153-168. DOI: 10.1016/j.chemgeo.2005.07.019.

Cardigos, F.; Ferraz, R.R.; Vizinho, S.; Santos, V.; Guerreiro, V.; Tempera, F.; Frade, P.; Santos, R.S. (2004) - Caracterização Ecológica e Sócio-Económica do Sítio de Importância Comunitária Banco D. João de Castro (PTMIG0021) e Medidas de Gestão Propostas. Arquivos do DOP. Série Relatórios Internos, (ISSN: 0873-2841), 21:1-73, Universidade dos Açores, Departamento de Oceanografia e Pescas, Horta, Açores, Portugal. Available on-line at http://www.horta.uac.pt/projectos/macmar/ogamp/PlanosGestao/PG_SI C/PG_OGAMP_DJoao_Castro.pdf.

Cardigos, F.; Tempera, F.; Ávila, S.; Gonçalves, J.; Colaço, A.; Santos, R.S. (2006) - Non-indigenous marine species of the Azores. Helgoland Marine Research, 60:160-169. DOI: 10.1007/s10152-006-0034-7.

Colaço, A.; Raghukumar, C.; Mohandass, C.; Cardigos, F.; Santos, R.S. (2006) - Effect of shallow-water venting in Azores on a few marine biota. Cahiers de Biologie Marine, (ISSN: 22623094), 47(4):359-364. Available on-line at http://drs.nio.org/drs/handle/2264/685

Couto, R.P.; Neto, A.I.; Rodrigues, A.S. (2010) - Metal concentration and structural changes in Corallina elongata (Corallinales, Rhodophyta) from hydrothermal vents. Marine Pollution Bulletin, 60(4):509-514. DOI: 10.1016/j.marpolbul.2008.11.020.

Couto, R.P.; Neto, A.I.; Rodrigues, A.S. (2012) - Limpet shell modifications at intertidal hydrothermal vents. Journal of Integrated Coastal Zone Management, (ISSN: 1646-8872), 12(2):253-256. DOI: $10.5894 /$ rgci327. 
Cruz, J.V. (2003) - Groundwater and volcanoes: examples from the Azores archipelago. Environmental Geology, 44:343-355. DOI: 10.1007/s00254-003-0769-2.

Cruz, J.V.; Coutinho, R.M.; Carvalho, M.R.; Oskarsson, N.; Gislason, S.R. (1999) - Chemistry of waters from Furnas volcano, São Miguel, Azores: fluxes of volcanic carbon dioxide and leached material. Journal of Volcanology and Geothermal Research, 92:151-167. DOI: 10.1016/S0377-0273(99)00073-6.

Cruz, J.V.; França, Z. (2006) - Hydrogeochemistry of thermal and mineral water springs of the Azores archipelago (Portugal). Journal of Volcanology and Geothermal Research, 151:382398. DOI: $10.1016 /$ j.jvolgeores.2005.09.001.

Cruz, J.V.; Freire, P.; Costa, A. (2010) - Mineral waters characterization in the Azores archipelago (Portugal). Journal of Volcanology and Geothermal Research, 190(3-4):353-364. DOI: 10.1016/j.jvolgeores.2009.12.001.

Cunha, L.; Amaral, A.; Medeiros, V.; Martins, G.M.; Wallenstein, F.F.M.M.; Couto, R.P.; Neto, A.I.; Rodrigues, A. (2008) Bioavailable metals and cellular effects in the digestive gland of marine limpets living close to shallow water hydrothermal vents. Chemosphere, 71:1356-1362. DOI: 10.1016/j.chemosphere.2007.11.022.

Cunha, L.; Martins, G.M.; Amaral, A.; Rodrigues, A. (2007) - A case of simultaneous hermaphroditism in the Azorean endemic limpet Patella candei gomesii (Mollusca: Patellogastropoda), a gonochoristic species. Invertebrate Reproduction and Development, 50:4:203-205. DOI: 10.1080/07924259.2007.9652247.

d'Acoz, C. d'Udekem; Wirtz, P. (1999) - List of animal species seen during four dives at the Banco João de Castro. In: Advanced System Integration for Managing the coordinated operation of robotic Ocean Vehicles (AZIMOV). Available on-line at http://www.horta.uac.pt/projectos/asimov/1999/PW_CA_contribution.ht $\mathrm{m}$

Dando, P.R.; Hughes, J.A.; Leahy, Y.; Niven, S.J.; Taylor, L.J.; Smith, C. (1995) - Gas venting rates from submarine hydrothermal areas around the island of Milos, Hellenic Volcanic Arc. Continental Shelf Research, (ISSN: 0278-4343), 15(8):913-929. DOI: 10.1016/0278-4343(95)80002-U.

Dando, P.R.; Stüben, D.; Varnavas, S.P. (1999) - Hydrothermalism in the Mediterranean Sea. Progress in Oceanography, 44:333367. DOI: $10.1007 / \mathrm{s} 10152-012-0341-0$.

Daussy, M. (1830) - Notice sur l'île volcanique qui a paru, en 1720, entre les îles Tercères et Saint-Michel aux Açores. Annales Maritimes et Coloniales, Année 1830, tome I, $2^{\mathrm{e}}$ Partie:60-61.

Desbruyéres, D.; Biscoito, M.; Caprais, J.-C.; Colaço, A.; Comtet, T.; Crassous, P.; Fouquet, Y.; Khripounoff, A.; Bris, N.L.; Olu, K.; Riso, R.; Sarradin, P.-M.; Segonzac, M.; Vangriesheim, A. (2001) - Variations in deep-sea hydrothermal vent communities on the Mid-Atlantic Ridge near the Azores plateau. Deep-Sea Research I, 48:1325-1346. DOI: 10.1016/S09670637(00)00083-2.

Dionísio, M.; Costa, A.; Rodrigues, A. (2013) - Heavy metal concentrations in edible barnacles exposed to natural contamination. Chemosphere, 91:563-570. DOI: 10.1016/j.chemosphere.2013.01.006.

Ferreira, T. (1994) - Contribuição para o estudo das emanações gasosas associadas a processos de vulcanismo no Arquipélago dos Açores. 183p., Provas de Aptidão Pedagógica e Capacidade Científica, Universidade dos Açores, Ponta Delgada, Açores, Portugal. Unpublished.

Ferreira, T.; Gaspar, J.L.; Viveiros, F.; Marcos, M.; Faria, C.; Sousa, F. (2005) - Monitoring of fumarole discharge and $\mathrm{CO}_{2}$ soil degassing in the Azores: contribution to volcanic surveillance and public health risk assessment. Annals of Geophysics, 48(45):787-796. DOI: $10.4401 / \mathrm{ag}-3234$.

Ferreira, T.; Oskarsson, N. (1999) - Chemistry and isotopic composition of fumarole discharges of Furnas caldera. Journal of Volcanology and Geothermal Research, 92(1-2):169-179. DOI: 10.1016/S0377-0273(99)00074-8.

França, Z.; Cruz, J.V.; Nunes, J.C.; Forjaz, V.H. (2003) - Geologia dos Açores: uma perspectiva actual. Açoreana, (ISSN: 08740380), 10(1):11-140, Sociedade Afonso Chaves, Porta Delgada, Açores, Portugal.

Hall-Spencer, J.M.; Rodolfo-Metalpa, R.; Martin, S.; Ransome, E.; Fine, M.; Turner, S.M.; Rowley, S.J.; Tedesco, D.; Buia, M.C. (2008) - Volcanic carbon dioxide vents show ecosystem effects of ocean acidification. Nature, 454:96-99. DOI: 10.1038/nature07051.

Hansell, A.L.; Horwell, C.J.; Oppenheimer, C. (2006) - The health hazards of volcanoes and geothermal areas. Occupational and Environmental Medicine, 63:149-156. DOI: 10.1136/oem.2005.022459.

Huber, R.; Langworthy, T.A.; König, H.; Thomm, M.; Woese, C.R.; Sleytr, U.B.; Stetter, K.O. (1986) - Thermotoga maritima sp. nov. represents a new genus of unique extremely thermophilic eubacteria growing up to $90^{\circ} \mathrm{C}$. Archives of Microbiology, 144:324-333. DOI: 10.1007/BF00409880.

Instituto Hidrográfico (2000) - Roteiro da costa de Portugal: Arquipélago dos Açores. $2^{\mathrm{a}}$ ed., 233 p., Instituto Hidrográfico, Lisboa. ISBN: 972848609X

Manaia, C.M.; Costa, M.S.d. (1991) - Characterization of halotolerant Thermus isolates from shallow marine hot springs on S. Miguel, Azores. Journal of General Microbiology, 137:2643-2648. DOI: 10.1099/00221287-137-11-2643.

Manaia, C.M.; Hoste, B.; Gutierrez, M.C.; Gillis, M.; Ventosa, A.; Kersters, K.; Costa, M.S.d. (1994) - Halotolerant Thermus strains from marine and terrestrial hot springs belong to Thermus thermophilus (ex Oshima and Imahori, 1974) nom. rev. emend. Systematic and Applied Microbiology, 17(4):526-532. DOI: $10.1016 / \mathrm{S} 0723-2020(11) 80072-\mathrm{X}$.

Marshall, D.J.; Santos, J.H.; Leung, K.M.Y.; Chak, W.H. (2008) Correlations between gastropod shell dissolution and water chemical properties in a tropical estuary. Marine Environmental Research, 66:422-429. DOI: 10.1016/j.marenvres.2008.07.003.

Martin, S.; Rodolfo-Metalpa, R.; Ransome, E.; Rowley, S.J.; Buia, M.C.; Gattuso, J.P.; Hall-Spencer, J.M. (2008) - Effects of naturally acidified seawater on seagrass calcareous epibionts. Biology Letters, 4:693-695. DOI: 10.1098/rsbl.2008.0412.

MBL (2009) - ASV - Azorean Shallow Vents. In: International Census of Marine Microbes (ICoMM). Available on-line at http://icomm.mbl.edu/microbis/project_pages/details/index.php?project $=\mathrm{ASV}$.

Melwani, A.R.; Kim, S.L. (2008) - Benthic infaunal distributions in shallow hydrothermal vent sediments. Acta Oecologica, 33(2):162-175. DOI: 10.1016/j.actao.2007.10.008.

Mendes, A.R.M. (2008) - Influência Das Fontes Hidrotermais Marinhas De Baixa Profundidade Na Composição Das Comunidades De Meiofauna. 38 p., Biology Degree Thesis, Universidade dos Açores, Ponta Delgada, Açores, Portugal. Unpublished.

Mohandass, C.; Rajasabapathy, R.; Ravindran, C.; Colaço, A.; Santos, R.S.; Meena, R.M. (2012) - Bacterial diversity and their adaptations in the shallow water hydrothermal vent at D. João de Castro Seamount (DJCS), Azores, Portugal. Cahiers de Biologie Marine, (ISSN: 2262-3094), 53:65-76. Available on-line at http://www.frontiersin.org/profile/publications/23849629.

Moore, P.G.; Rainbow, P.S.; Weeks, J.M.; Smith, B. (1995) Observations on copper and zinc in an ecological series of 
talitroidean amphipods (Crustacea: Amphipoda) from the Azores. Açoreana, (ISSN: 0874-0380), Supplement:93-102. http://books.google.pt/books?id=RGzrXwAACAAJ.

Morton, B.; Britton, J.C.; Martins, A.M.F. (1998) - Coastal Ecology of the Açores, 249p., Sociedade Afonso Chaves, Ponta Delgada, Açores, Portugal. ISBN: 9729777403

Munaro, M.; Boccolato, G.; Ferreira, F.; Gracias, N.; Sebastião, L.; Sotiropoulos, P.; Tempera, F.; Wordley, S. (2010) - Azores FREEsubNET Workshop: Habitat Mapping of Espalamaca Vents and Monte da Guia. In: M. Schmiing (Ed.), Final FREEsubNET Workshop Report, pp. 29, Freesubnet Project, Horta, Faial, Azores, Portugal. Available on-line at http://www.horta.uac.pt/intradop/images/stories/eventos/freesubnet/Rep ortWorkshopAzores.pdf

Nunes, O.C.; Donato, M.M.; Da Costa, M.S. (1992) - Isolation and Characterization of Rhodothermus Strains from S. Miguel, Azores. Systematic and Applied Microbiology, 15(1):92-97. DOI: 10.1016/S0723-2020(11)80144-X.

O'Hara, S.C.M.; Dando, P.R.; Schuster, U.; Bennis, A.; Boyle, J.D.; Chui, F.T.W.; Hatherell, T.V.J.; Niven, S.J.; Taylor, L.J. (1995) - Gas seep induced interstitial water circulation: observations and environmental implications. Continental Shelf Research, 15(8):931-948. DOI: 10.1016/0278-4343(95)80003-V.

Oliveira, A. (1943) - Banco D. João de Castro. Trabalhos da Missão Hidrográfica das Ilhas Adjacentes: 1-19.

Raghukumar, C.; Mohandass, C.; Cardigos, F.; D'Costa, P.M.; Santos, R.S. (2008) - Assemblage of benthic diatoms and culturable heterotrophs in shallow-water hydrothermal vent of the D. João de Castro Seamount, Azores in the Atlantic Ocean. Current science, (ISSN: 0011-3891), 95(12):1715-1723. Available on-line at http://drs.nio.org/drs/handle/2264/2114.

Riebesell, U. (2008) - Acid test for marine biodiversity. Nature Reports Climate Change, 2:105-106. DOI: 10.1038/454046a.

Riebesell, U.; Fabry, V.J.; Hansson, L.; Gattuso, J.-P. (2010) Guide to best practices for ocean acidification research and data reporting., 260p., Publications Office of the European Union, Luxembourg. ISBN: 978-9279111181

Santos, R.S.; Gonçalves, J.; Cardigos, F. (1996) - D. João de Castro Bank. In, Report to the European Community under the research project "Biogeography and biodiversity of hydrothermal vents and cold seeps: an international co$\begin{aligned} & \text { operative study" reference number: INTAS-94-0592, 3p. } \\ & \text { Available }\end{aligned}$
on-line

http://www.horta.uac.pt/projectos/asimov/Bibliography/Santos/Tp.pdf

Santos, R.S.; Pascoal, A.; Dando, P.; Cardigos, F.; Tempera, F.; Oliveira, P.; Silvestre, C.; Cardew, M. (2001) - Remote sensing at D. João de castro bank: tools for biology and conservation studies. In, Proceedings of the 5th Underwater Science Symposium, pp. 5, Society for Underwater Technology (SUT), Southampton, United Kigdom. Available on-line at http://welcome.isr.ist.utl.pt/img/pdfs/1153_soc2001.pdf

Searle, R. (1980) - Tectonic pattern of the Azores spreading centre and triple junction. Earth and Planetary Science Letters, 51(2):415-434. DOI: 10.1016/0012-821X(80)90221-6.

Segerer, A.H.; Trincone, A.; Gahrtz, M.; Stetter, K.O. (1991) Stygiolobus azoricus gen. nov., sp. nov. Represents a Novel Genus of Anaerobic, Extremely Thermoacidophilic Archaebacteria of the Order Sulfolobales. International Journal of Systematic Bacteriology, 41(4):495-501. DOI: 10.1099/00207713-41-4-495.
Tarasov, V.G.; Gebruk, A.V.; Mironov, A.N.; Moskalev, L.I. (2005) - Deep-sea and shallow-water hydrothermal vent communities: Two different phenomena? Chemical Geology, 224:5-39. DOI: 10.1016/j.chemgeo.2005.07.021.

Vedel, G.; Depledge, M. (1995) - Temperature tolerance and selected trace metal concentrations in some azorean gastropod molluscs. Açoreana, (ISSN: 0874-0380), Supplement:113-124, Sociedade Afonso Chaves, Porta Delgada, Açores, Portugal.

Viveiros, F.; Cardellini, C.; Ferreira, T.; Caliro, S.; Chiodini, G.; Silva, C. (2010) - Soil CO2 emissions at Furnas volcano, São Miguel Island, Azores archipelago: Volcano monitoring perspectives, geomorphologic studies, and land use planning application. Journal of Geophysical Research: Solid Earth, 115(B12):B12208. DOI: 10.1029/2010jb007555.

Viveiros, F.; Ferreira, T.; Cabral Vieira, J.; Silva, C.; Gaspar, J.L. (2008) - Environmental influences on soil CO2 degassing at Furnas and Fogo volcanoes (São Miguel Island, Azores archipelago). Journal of Volcanology and Geothermal Research, 177(4):883-893. DOI: 10.1016/j.jvolgeores.2008.07.005.

Wallenstein, F.M.; Couto, R.P.; Amaral, A.S.; Wilkinson, M.; Neto, A.I.; Rodrigues, A.S. (2009a) - Baseline metal concentrations in marine algae from São Miguel (Azores) under different ecological conditions - Urban proximity and shallow water hydrothermal activity. Marine pollution bulletin, 58:424-455. DOI: 10.1016/j.marpolbul.2008.11.020.

Wallenstein, F.M.; Couto, R.P.; Torrão, D.F.; Neto, A.I.; Rodrigues, A.S.; Wilkinson, M. (2013) - Intertidal rocky shore seaweed communities subject to the influence of shallow water hydrothermal activity in São Miguel (Azores, Portugal). Helgoland Marine Research, 67:535-543. DOI: 10.1007/s10152-012-0341-0.

Wallenstein, F.M.; Torrão, D.F.; Neto, A.I.; Wilkinson, M.; Rodrigues, A.S. (2009b) - Effect of exposure time on the bioaccumulation of $\mathrm{Cd}, \mathrm{Mg}, \mathrm{Mn}$ and $\mathrm{Zn}$ in Cystoseira abiesmarina samples subject to shallow water hydrothermal activity in São Miguel (Azores). Marine Ecology, 30(1):118-122. DOI: 10.1111/j.1439-0485.2009.00322.x.

Weeks, J.M.; Rainbow, P.S.; Depledge, M.H. (1995) - Barnacles (Chthamalus stellatus) as biomonitors of trace metal bioavailability in the waters of São Miguel (Azores). Açoreana, (ISSN: 0874-0380), Supplement:103-111, Sociedade Afonso Chaves, Porta Delgada, Açores, Portugal.

Zillig, W.; Holz, I.; Janekovic, D.; Klenk, H.-P.; Imsel, E.; Trent, J.; Wunderl, S.; Forjaz, V.H.; Coutinho, R.M.; Ferreira, T. (1990) Hyperthermus butylicus, a Hyperthermophilic Sulfur-Reducing Archaebacterium that ferments peptides. Journal of Bacteriology, 172:7:3959-3965. Available on-line at http://www.ncbi.nlm.nih.gov/pubmed/2113915.

Zillig, W.; Holz, I.; Wunderl, S. (1991) - Hyperthermus butylicus gen. nov., sp. nov., a Hyperthermophilic, Anaerobic, PeptideFermenting, Facultatively H2S-Generating Archaebacterium. International Journal of Systematic Bacteriology, 41(1):169170. DOI: 10.1099/00207713-41-1-169.

Zinger, L.; Amaral-Zettler, L.A.; Fuhrman, J.A.; Horner-Devine, M.C.; Huse, S.M.; Welch, D.B.M.; Martiny, J.B.H.; Sogin, M.; Boetius, A.; Ramette, A. (2011) - Global Patterns of Bacterial Beta-Diversity in Seafloor and Seawater Ecosystems. PLoS ONE, 6(9):e24570. DOI: 10.1371/journal.pone.0024570. 